\title{
Genetic Engineering of Local Cayenne Pepper (Capsicum frustescens L.) Through Breeding With Multigamma Irradiation Methods to Obtain Superior Offspring
}

\author{
Bartholomeus Pasangka ${ }^{1} \&$ Abdul Wahid ${ }^{2}$ \\ ${ }^{1}$ Department of Physical and Agricultural Sciences, Nusa Cendana University, Indonesia \\ ${ }^{2}$ Department of Physics, Nusa Cendana University, Indonesia \\ Correspondence: Bartholomeus Pasangka, Department of Physical and Agricultural Sciences, Nusa Cendana \\ University, Indonesia. Tel: 62-822-3704-4338. E-mail: bpasangka15@gmail.com; b.pasangka@staf.undana.ac.id
}

\author{
Received: July 15, $2021 \quad$ Accepted: October 27, $2021 \quad$ Online Published: November 15, 2021 \\ doi:10.5539/jas.v13n12p81 URL: https://doi.org/10.5539/jas.v13n12p81
}

\begin{abstract}
This study purpose to genetically engineer local cayenne pepper through breeding with multigamma irradiation methods to obtain superior offspring that adapt to drought stress, extreme weather, pest tolerance, and high production. The method used consists of observation, sampling, irradiation, careful selection, purification, comparative, and interpretation. The brief procedure of the study included: observations for taking samples, inventorying the physical characteristics of local chili parent varieties, selecting research sites, cultivating the planting area, irradiating the sample at a dose of 2500 rads for 30 minutes, soaking the planting area, planting seeds, irrigation, observing the age and ability to grow seeds, doing embroidery, weeding and fertilizing, observing the condition of plants during growth, harvesting, weighing the mass of fruit per tree, analyzing several nutritional content, comparing the physical and chemical characteristics of the parent varieties and selected superior offspring, and interpreting. Result of research: Local cayenne pepper of superior selected offspring as a result of multigamma irradiation can adapt to drought conditions, extreme weather, tolerant of pests and diseases, and significantly increase production compared to the parent variety. The average production of the selected superior offspring was $11.11 \mathrm{t} \mathrm{ha}^{-1}$, while the parent variety was $6.54 \mathrm{t} \mathrm{ha}^{-1}$ with a percentage increase in the production of local cayenne pepper from the selected superior offspring was $41.13 \%$.
\end{abstract}

Keywords: cayenne pepper, breeding, genetic, multigamma irradiation, superior offspring

\section{Introduction}

\subsection{The Problem and Purpose of Research}

The main problem investigated in this work was genetic engineering of local cayenne pepper through breeding to use multigamma irradiation. The purpose of this research is genetic engineering of local cayenne pepper through breeding with multigamma irradiation method to obtain superior offspring that can adapt to less water and extreme weather, tolerant of pests and diseases, and high production.

\subsection{The Origin of Cayenne Pepper}

Cayenne pepper belongs to the eggplant family (Solanaceae) originating from Peru, the American continent which then spread throughout America, Europe, Africa, and Asia. In the 16th century, Portuguese and Spanish traders introduced chili originating from South America to Asia and Africa through trade routes (Law et al., 2015; Assagaf, 2017). More than 100 chili species have been identified, of which 5 have been cultivated, namely Casicum, Annuum, Chinense, Frutescens, Baccatum, and Pubescens (Effendi et al., 2018).

\subsection{The Importance of Cayenne Pepper Developed}

Cayene Pepper is one of the important vegetable crops (horticultural commodities) because of its high nutritional content, especially cayenne pepper, has many benefits for consumers (Sofa et al., 2019), and has high economic value (Wulandari et al., 2018; Eliyatiningsih \& Mayasari, 2019). The nutritional content or nutrients in 100 grams $(\mathrm{g})$ of cayenne pepper are: $4.7 \mathrm{~g}$ protein, $4.2 \mathrm{~g}$ fat, $19.9 \mathrm{~g}$ carbohydrates, $45 \mathrm{mg}$ calcium, $8 \mathrm{mg}$ phosphorus, $11 \mathrm{mg}$ vitamin A, $70 \mathrm{mg}$ vitamin C, and 103 calories of energy (Assagaf, 2017; Hayatudin, 2021). Cayenne pepper contains resin, carotenoids, capsantin and capsaicin which give a spicy taste (Silvia et al., 2016; 
Alimuddin et al., 2019), volatile alkaloids, volatile oil, vitamins A and C, tannins, phenols, flavonoids, anthraquinones, saponins, glucosides, limonoids, terpenoids, and carotenoids (Kusnadi et al., 2019), dihydrocapsainin, capsainoid, beta carotene (Sutomo et al., 2017), mineral salts such as calcium, iron, potassium, and phosphorus (Asmal, 2018), and in cayenne pepper seeds contained solanine, solamargarine, solamidine, solasomine, solasodine, and steroids. The special nutritional content in cayenne pepper includes vitamin $\mathrm{A}=$ $11.8836 \mathrm{IU} / 11 \mathrm{~g}$, vitamin $\mathrm{B}=763.52 \mathrm{ppm}$, protein $=5.83 \%$ (Mahyudi, 2015).

\subsection{Literatures Study}

Chili which is one of the leading national horticultural commodities experiences fluctuations in production from year to year (Nurjanni, 2016) so that it is not comparable to the demand for chili needs among the people which continues to increase (Septiadi et al., 2020; Prabowo et al., 2018; Wachdijono, 2020; Salampessy et al., 2019). The results of the BPS survey (2017) reported that the consumption of cayenne pepper in 2013 was 316.57 thousand tons per year, and in 2014 it increased to 318.21 thousand tons per year. The relatively high demand for cayenne pepper is caused by the content of nutrients that are needed for health (Fitri et al., 2020). Some areas producing cayenne pepper in Indonesia experienced a decline in production, including: (1) Cayenne pepper production in Aceh in 2015 was 58,918 tons (t) per year, decreased to 46,405 t in 2016, and in 2018 cayenne pepper production in Aceh decreased to 62,167 t to 61,887 t in 2019; (2) Cayenne pepper production in South Sumatra in 2017 was $15,826 \mathrm{t}$ per year, decreased to $13,451 \mathrm{t}$ in 2018, and 11,014 t in 2019; (3) Lampung area: cayenne pepper production in 2017 was 14,705 $t$ decreased to 14,648 $t$ in 2018, 12,796 $t$ in 2019; (4) In 2017 the production of cayenne pepper in West Java amounted to 13,910 t, decreased to 131,418 $\mathrm{t}$ in 2018, and continued to decline in 2019 to 128,494 t; (5) Cayenne pepper production in West Kalimantan in 2016 was 4,753 t, down to 4,719 $\mathrm{t}$ in 2017, and production continued to decline in 2018 to 4,165 t; (6) In 2017, the production of cayenne pepper in Maluku was 4,039 t, down to 3,732 $t$ in 2018, and continued to decline in 2019 to 3,440 t; (7) Cayenne pepper-producing areas that have decreased production for 3 consecutive years are West Papua, namely production of 1,304 $\mathrm{t}$ in 2016, $889 \mathrm{t}$ in 2017, and $625 \mathrm{t}$ in 2018 (BPS, 2019). In 2012-2015, the production of cayenne pepper in North Central Timor Regency decreased successively, namely $66.6 \mathrm{t}$ (in 2012), $63.5 \mathrm{t}$ (in 2013), $50.8 \mathrm{t}$ (in 2014) and $35.5 \mathrm{t}$ (in 2015) (Bete \& Taena, 2018).

The low productivity of chili is caused by several factors, including: (1) the use of superior varieties of seeds is still relatively lacking (Azwir et al., 2018); (2) the use of types of fertilizers with inappropriate doses (Adetya et al., 2018; Ernita et al., 2020; Hutubessy, 2017; Ilyasa et al., 2018; Karim et al., 2019); (3) pest control has not maximum; (4) inadequate planting of land; (5) the presence of toxic elements in the soil in chili plants (Edy et al., 2017); (6) inadequate irrigation; (7) post-harvest processing adequate (Edowai et al., 2016; Putri et al., 2020 ).

\subsection{Problem Solution}

To increase the productivity of cayenne pepper, the first step that must be taken is the procurement of superior variety seeds through breeding using modern technology. One of the effective and efficient methods that requires a relatively short time is the breeding of cayenne pepper with Nuclear Techniques (multigamma irradiation).

\section{Method}

\subsection{Research Sites}

Samples of local cayenne pepper developed in this study were taken at the center of cayenne pepper farmers' plantations in Fukdale Kupang Timur, Kefamenanu, and Malaka. The irradiation of local cayenne pepper samples was carried out at the Mini Nuclear Bioscience Laboratory, Nusa Cendana University. Planting locations are carried out in farmers' gardens in four provinces, namely East Penfui, East Nusa Tenggara Province, Mamuju, West Sulawesi Province, Tinoring, South Sulawesi Province, and Palu, Central Sulawesi Province.

\subsection{Research Method}

The methods used in this study include observation: carry out activities for sampling local cayenne pepper and determining planting locations (research locations), sampling: Sampling of local cayenne pepper at farmer's plantation centers in Menado North Sulawesi and Palu Central Sulawesi, irradiation: irradiation of local cayenne pepper seed samples at a dose of 2500 rads for 30 minutes, careful selection: selecting cayenne pepper plants individually starting at the age of 30 days after planting until harvesting is complete, analysis: calculate the percentage of seed growth, average production, and the percentage increase in cayenne pepper production, comparative: Comparing the characteristics of superior offspring varieties with their parent varieties, and interpretation: interpret the results that have been achieved. 


\subsection{Research Procedure}

The brief procedure of this research includes: (1) observations for sampling local cayenne pepper, selection of research sites, and collecting characteristics of parent varieties; (2) irradiation of samples; (3) cultivation of planting land; (4) planting; (5) observation of early seed growth; (6) weeding, fertilizing, and watering; (7) individual plant selection; (8) observation during growth (pest and disease resistance, adaptation to water shortages, and extreme weather; (9) harvesting, drying, and storage; (10) analysis of several nutrients.

\subsection{Mathematical Equations for Data Analysis}

The mathematical formulation required for data analysis consists of (Pasangka and Rfli, 2016; Pasangka and Irvandi, 2021).

2.4.1 Calculation of the Percentage of Growing Local Cayenne Pepper Seeds on Superior Offspring and Parent Variety

Treatment sample:

$$
P G_{T S}=\left(\frac{T_{A S}-A_{T S}}{T_{A S}}\right) \times 100 \%
$$

Where, $P G_{T S}$ : percentage of growth on treatment (\%), $T_{A S}$ : the total number of seeds planted, $A_{T S}$ : number of seeds that did not grow on treatment sample.

Control sample:

$$
P G_{C S}=\left(\frac{T_{A S}-A_{C S}}{T_{A S}}\right) \times 100 \%
$$

Where, $P G_{C S}$ : percentage of growth on control sample (\%), $A_{C S}$ : the number of seeds that did not grow on control sample (\%).

2.4.2 Calculation of the Average Production of Selected Superior Offspring at the Four Planting Locations

$$
A_{P T S}=\frac{P_{L 1}+P_{L 2}+P_{L 3}+P_{L 4}}{4}
$$

Where, $A_{P T S}$ : the average production of selected superior offspring (t/ha), $P_{L 1}, P_{L 2}, P_{L 3}$ : production of superior offspring and control samples in four planting locations.

2.4.3 Calculation of the Average Production in the Control Sample at the Four Planting Locations

$$
A_{P C S}=\frac{P_{L 1}+P_{L 2}+P_{L 3}+P_{L 4}}{4}
$$

Where, $A_{P C S}$ : the average production of control sample.

2.4.4 Mathematical Formulation to Calculate the Average Percentage Increase in Production

$$
I_{P A P}=\left(\frac{A_{P T S}-A_{P C S}}{A_{P T S}}\right) \times 100 \%
$$

Where, $I_{P A P}$ : percentage increase in average production (\%).

\section{Results}

\subsection{Observation, Measurement, and Calculation Results}

The results obtained based on observation, measurement, and calculation data show the physical characteristics of local cayenne pepper varieties of parent and offspring developed through breeding using multigamma (nuclear) irradiation methods and careful selection to obtain superior offspring that can adapt to drought conditions (lack of land water), extreme climate, pest-disease tolerance, and high production. The real results obtained are shown in Figures 1a, 1b, 2a, and 2b, Tables 1-3 as follows. 


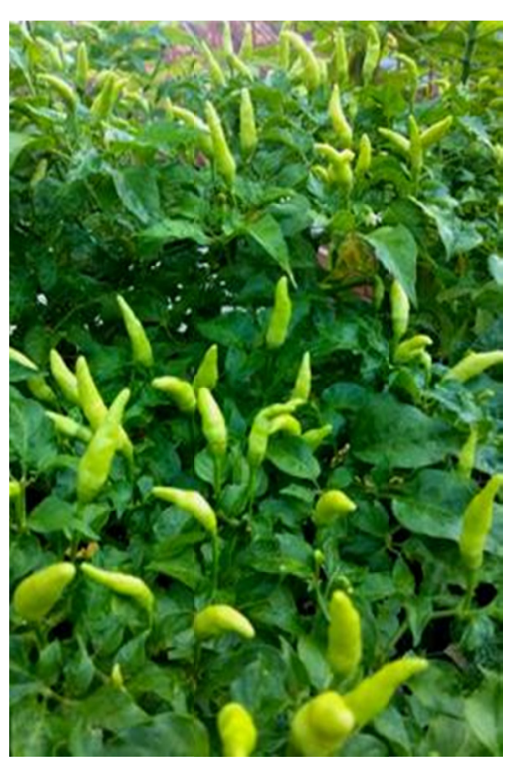

Figure 1a. Show an example of local cayenne pepper fruit of selected superior offspring at the age of 48 days after planting (d a p)

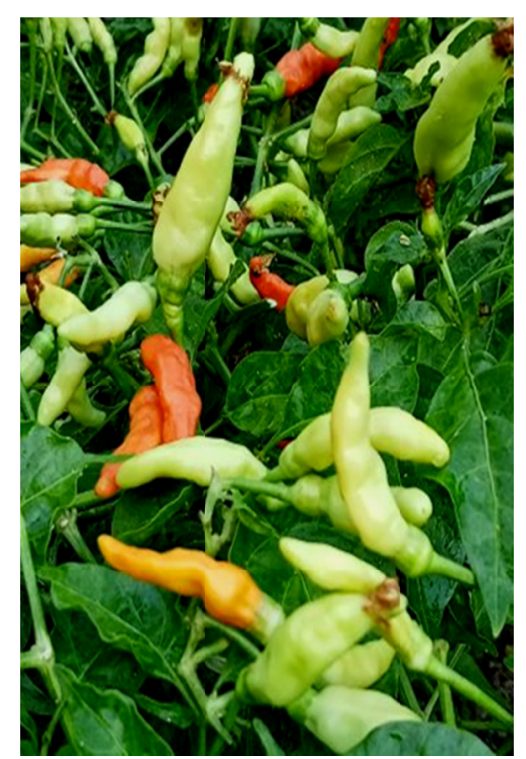

Figure 1b. Show an example of local cayenne pepper fruit of selected superior offspring at the age $80 \mathrm{~d}$ a $\mathrm{p}$ 


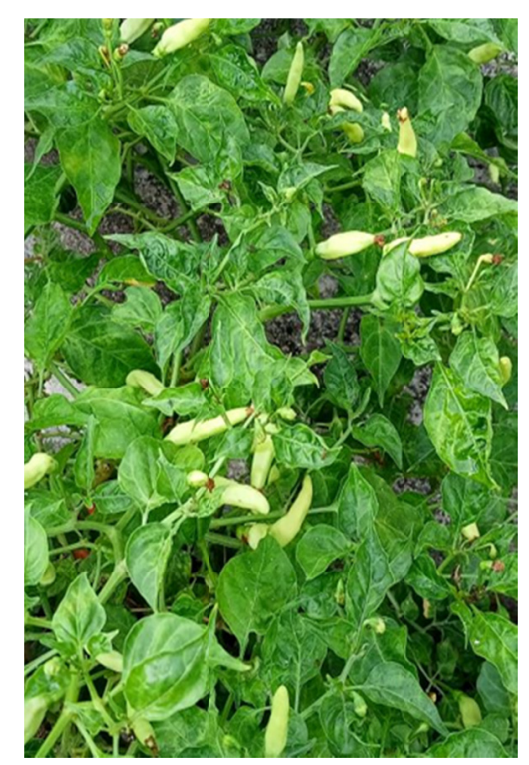

Figure 2a. Show an example of local cayenne pepper fruit of parent variety at the age of $80 \mathrm{~d}$ a $\mathrm{p}$

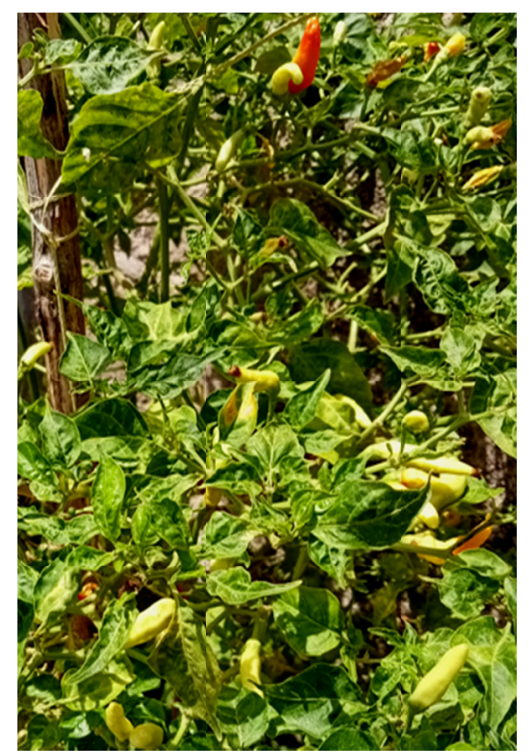

Figure $2 \mathrm{~b}$. Show an example of local cayenne pepper fruit of parent variety at the age of $100 \mathrm{~d}$ a $\mathrm{p}$

\subsection{Data to Calculate the Percentage of Growing Seeds}

To calculate the percentage of growing local cayenne pepper seeds in the control sample and the treatment sample, five (5) groups of samples were taken randomly with the number of seeds observed as many as 30 seeds in each group. The treatment sample consisting of five (5) groups was taken with five (5) variations of observations which are clearly visible in Table 1 . 
Table 1. The results of the observation of the number of cayenne pepper seeds that did not grow in the control and the treatment samples

\begin{tabular}{|c|c|c|c|c|c|c|c|}
\hline \multirow{3}{*}{ GS } & \multirow{3}{*}{ Number of seeds in each group } & \multirow{3}{*}{$\mathrm{CS}$} & \multicolumn{5}{|c|}{ Number of seeds that do not grow } \\
\hline & & & \multicolumn{5}{|c|}{ Selected Superior Offspring } \\
\hline & & & 1 & 2 & 3 & 4 & 5 \\
\hline I & 30 & 8 & 4 & 5 & 3 & 5 & 4 \\
\hline II & 30 & 10 & 6 & 5 & 7 & 4 & 5 \\
\hline III & 30 & 9 & 5 & 3 & 4 & 7 & 5 \\
\hline IV & 30 & 9 & 4 & 6 & 6 & 5 & 7 \\
\hline $\mathrm{V}$ & 30 & 11 & 7 & 6 & 7 & 3 & 5 \\
\hline & Average $=30$ & 9.40 & 5.20 & 5.00 & 5.40 & 4.80 & 5.20 \\
\hline & The total average in the selected superior offspring & & & & 5.12 & & \\
\hline & Percentage of Growth in control and treatment samples & $68.67 \%$ & $82.67 \%$ & $83.33 \%$ & $82.00 \%$ & $84.00 \%$ & $82.67 \%$ \\
\hline & Average total of growth percentage & $68.67 \%$ & & & $82.93 \%$ & & \\
\hline
\end{tabular}

Note. GS: Group Sample; CS: Control Sample.

Table 2. Important physical and chemical characteristics from observations, measurements, and calculations on local cayenne pepper parent and selected superior offspring

\begin{tabular}{|c|c|c|c|}
\hline No. & Description & Parent Variety & Selected Superior Offspring \\
\hline 1 & Growing time & 11 days after planting ( $\mathrm{d}$ a $\mathrm{p}$ ) & 7 days after planting ( $\mathrm{d}$ a $\mathrm{p}$ ) \\
\hline 2 & Growth percentage & $68.67 \%$ & $82.93 \%$ \\
\hline 3 & Flowering age range & $(78-97) \mathrm{d}$ a $\mathrm{p}$ & $(43-55) d a p$ \\
\hline 4 & Average flowering age & $83 \mathrm{~d}$ a p & $48 \mathrm{~d}$ a $\mathrm{p}$ \\
\hline 5 & Plant height range & $(82.5-108.5) \mathrm{cm}$ & $(92.3-130.0) \mathrm{cm}$ \\
\hline 6 & Average plant height & $98.5 \mathrm{~cm}$ & $115.5 \mathrm{~cm}$ \\
\hline 7 & Adapt to dry land and extreme weather & Less adaptive & Adaptive \\
\hline 8 & Pests and diseases tolerant & Less tolerant & Tolerant \\
\hline 9 & Harvest age range & $(114-125) \mathrm{d} a \mathrm{p}$ & $(70-95) \mathrm{d}$ a $\mathrm{p}$ \\
\hline 10 & Average harvest age & $118 \mathrm{~d}$ a p & $88 \mathrm{~d}$ a p \\
\hline 11 & Fruit length range & $(1.20-2.16) \mathrm{cm}$ & $(2.31-3.50) \mathrm{cm}$ \\
\hline 12 & Average length of fruit & $1.97 \mathrm{~cm}$ & $2.85 \mathrm{~cm}$ \\
\hline 13 & Fruit diameter range & $(1.25-1.95) \mathrm{cm}$ & $(2.20-3.25) \mathrm{cm}$ \\
\hline 14 & Average fruit diameter & $1.65 \mathrm{~cm}$ & $2.86 \mathrm{~cm}$ \\
\hline 15 & Range of fruit per tree & $96-155$ & $127-215$ \\
\hline 16 & Average number of fruits per tree & 115 & 185 \\
\hline 17 & Fruit mass range per tree & $(300-400) \mathrm{g}$ & $(550-750) \mathrm{g}$ \\
\hline 18 & Average fruit mass per tree & $365 \mathrm{~g}$ & $650 \mathrm{~g}$ \\
\hline 19 & Young fruit color & Green & Green \\
\hline 20 & Ripe fruit color & Dark red & Light red \\
\hline 21 & Production range & $(5.83-7.15) \mathrm{t} \mathrm{ha}^{-1}$ & $(10.78-11.29) \mathrm{t} \mathrm{ha}^{-1}$ \\
\hline 22 & Average production & $6.54 \mathrm{t} \mathrm{ha}^{-1}$ & $11.11 \mathrm{t} \mathrm{ha}^{-1}$ \\
\hline 23 & Maximum production potential & $7.15 \mathrm{t} \mathrm{ha}^{-1}$ & $11.29 \mathrm{t} \mathrm{ha}^{-1}$ \\
\hline 24 & Percentage of production increase & - & $41.13 \%$ \\
\hline 25 & Protein & $4.2 \mathrm{~g}$ & $4.9 \mathrm{~g}$ \\
\hline 26 & Calcium & $43.5 \mathrm{~g}$ & $51.3 \mathrm{mg}$ \\
\hline 27 & Phosphor & $7.8 \mathrm{mg}$ & $9.6 \mathrm{mg}$ \\
\hline 28 & Vitamin A & $10.5 \mathrm{mg}$ & $11.85 \mathrm{mg}$ \\
\hline 29 & Vitamin C & $68.2 \mathrm{mg}$ & $76.3 \mathrm{mg}$ \\
\hline 30 & Carbohydrate & $19.7 \mathrm{~g}$ & $16.8 \mathrm{~g}$ \\
\hline
\end{tabular}


Table 3. Production levels at the four planting sites in the control (parent variety) and the treatment samples (selected superior offspring)

\begin{tabular}{llll}
\hline No. & Planting Site & Parent Variety & Selected Superior Offspring \\
\hline 1 & East Penfui Province of East Nusa Tenggara Timur & $7.15 \mathrm{t} \mathrm{ha}^{-1}$ & $11.29 \mathrm{t} \mathrm{ha}^{-1}$ \\
2 & Mamuju Province of West Sulawesi & $5.83 \mathrm{t} \mathrm{ha}^{-1}$ & $11.26 \mathrm{t} \mathrm{ha}^{-1}$ \\
3 & Tinoring Province of South Sulawesi & $6.45 \mathrm{t} \mathrm{ha}^{-1}$ & $10.78 \mathrm{t} \mathrm{ha}^{-1}$ \\
4 & Palu Province of central Sulawesi & $6.72 \mathrm{t} \mathrm{ha}^{-1}$ & $11.12 \mathrm{t} \mathrm{ha}^{-1}$ \\
\hline & Average production & $6.54 \mathrm{t} \mathrm{ha}^{-1}$ & $11.11 \mathrm{t} \mathrm{ha}^{-1}$ \\
\hline
\end{tabular}

\subsection{Statistical Analysis}

The growth percentage of seed in the control and treatment samples calculated by using Equations (1) and (2), and data in Table 1 as follows.

The number of observed seeds that were randomly selected was 30 seeds, the average seed that did not grow in the control sample was 9.40 seeds. The average of seeds that did not grow in the selected superior offspring was 5.12 seeds.

Percentage of growth in the control sample:

$$
P G=\left(\frac{T_{A S}-A_{S G}}{T_{A S}}\right) \times 100 \%=\left(\frac{30-9.40}{30}\right) \times 100 \%=768.67 \%
$$

Percentage of growth in the treatment sample:

$$
P G=\left(\frac{T_{A S}-A_{S G}}{T_{A S}}\right) \times 100 \%=\left(\frac{30-5.12}{30}\right) \times 100 \%=82.93 \%
$$

Average production on control and treatment samples of cayenne pepper calculated by Equation (3) dan (4) and percentage of increase in production of selected superior offspring of local cayenne pepper as a result of multigamma irradiation calculated by Equation (5) as follows.

Average production in the control sample (parent variety) at the four planting sites:

$$
A_{P C S}=\frac{P_{L 1}+P_{L 2}+P_{L 3}+P_{L 4}}{4}=\left(\frac{7.15+5.83+6.45+6.72}{4}\right)=6.54 t h a^{-1}
$$

The average production of treatment sample or selected superior offspring of cayenne pepper from multigamma irradiation at the four planting sites:

$$
A_{P T S}=\frac{P_{L 1}+P_{L 2}+P_{L 3}+P_{L 4}}{4}=\left(\frac{11.29+11.26+10.78+11.12}{4}\right)=11.11 \mathrm{th}^{-1}
$$

Percentage of increase in production in selected superior offspring of local cayenne pepper as a result of multigamma irradiation:

$$
I_{P A P}=\left(\frac{A_{P T S}-A_{P C S}}{A_{P T S}}\right) \times 100 \%=\left(\frac{11.11-6.54}{11.11}\right) \times 100 \%=41.13 \%
$$

\section{Discussion}

4.1 Growing Time and Percentage of Seed Growth, Adaptation to Drought and Extreme Weather Conditions, Tolerance to Pests and Diseases

The growing time for the parent variety of local cayenne pepper was 11 days after planting (da p), while the high-yielding cultivars were selected 7 days after planting (d a p) with growth percentages of $68.67 \%$ (parent variety) and $82.93 \%$ (selected superior offspring). Figure 1 shows the growth of selected local cayenne peppers as a result of multigamma irradiation with thriving leaves, large and smooth fruits, while Figure 2 shows the growth of local cayenne peppers of parent varieties with rapidly yellowing leaves and small fruits. These data indicate that local chilies of superior breeds grow faster, adapt to drought and extreme weather conditions, and are tolerant of pests and diseases compared to their parent varieties. 


\subsection{Flowering and Harvesting Age}

The selected superior local cayenne pepper has a flowering age range (43-55) dap with an average flowering age of 48 dap, while the range and average flowering age of the parent variety are (78-97) dap and 83 dap, respectively. The harvest age range of the selected superior offspring was (70-95) dap with an average harvest age of 88 dap, while the harvest age range for the parent variety (114-125) dap with an average harvest age of 118 dap. This proves that the selected superior local cayenne peppers flower and harvest faster than their parent varieties.

\subsection{Production Rate and Percentage of Production Increase}

The number of fruits per tree in selected local cayenne peppers ranged from (127-215) fruit with an average fruit per tree of 185 fruit, while the range for the number of fruits in the parent variety was (96-155) fruit with an average number of fruits per tree 115 fruit. The mass for selected superior cayenne peppers per tree ranged between (550-750) $\mathrm{g}$ with an average mass per tree of $650 \mathrm{~g}$, while the mass range per tree of the parent variety was (300-400) $\mathrm{g}$ with an average mass of $365 \mathrm{~g}$. The production range of selected superior cayenne pepper was $(10.78-11.29) \mathrm{t} \mathrm{ha}^{-1}$, with an average production of $11.11 \mathrm{tha}^{-1}$, while the production range of the parent variety was (5.83-7.15) $\mathrm{t} \mathrm{ha}^{-1}$, with an average production of $6.54 \mathrm{t} \mathrm{ha}^{-1}$. This shows that the superior cayenne pepper selected as a result of multigamma irradiation has more fruit, higher mass per tree, and higher production than the parent variety with a percentage increase of $41.13 \%$ in production.

\subsection{Nutritional Content}

The content of several nutrients in selected local cayenne peppers includes protein $4.9 \mathrm{~g}$, calcium $51.5 \mathrm{mg}$, phosphorus $9.6 \mathrm{mg}$, vitamin A $11.85 \mathrm{mg}$, vitamin C $76.3 \mathrm{mg}$, and carbohydrates $16.8 \mathrm{~g}$, while the parent variety: protein $4.2 \mathrm{~g}$, calcium $43.5 \mathrm{~g}$, phosphorus $7.8 \mathrm{mg}$, vitamin A $10.5 \mathrm{mg}$, vitamin C $68.2 \mathrm{mg}$, and carbohydrates $19.7 \mathrm{~g}$. These data indicate that the nutritional content of selected high-yielding cayenne peppers is higher than the nutritional content of the parent varieties, except for carbohydrates.

\section{Conclusion}

The selected superior offspring of local cayenne pepper variety as a result of multigamma irradiation can adapt to drought conditions, extreme weather, tolerant to pest-disease, high nutrition content, and significantly increase production compared to the parent variety. The average production of the selected superior offspring was $11.11 \mathrm{t}$ $\mathrm{ha}^{-1}$ while the parent variety was $6.54 \mathrm{t} \mathrm{ha}^{-1}$ with a percentage increase in the production of local cayenne pepper from the selected superior offspring was $41.13 \%$.

\section{Acknowledgements}

This research was funded by the Regional Government of Tana Toraja South Sulawesi Indonesia Regency in collaboration with leading Research Experts. The publication fee of this manuscript included in this financial. Especial thanks to authorized official had been funded of this work and also especial thanks to the co-author who contributed to the writing of this manuscript.

\section{References}

Adetya, V., Nurhatika, S., \& Muhibuddin, A. (2018). The Effect of Microrhiza Fertilizer on the Growth of Cayenne Pepper (Capsicum frutescens L.) in Sand Soil. Journal of Science and Art ITS, 7(2), 2337-3520. https://doi.org/10.12962/j23373520.v7i2.37251

Alimuddin, Fatmawati, A. A., Nurmayulis, Arafiah, R., Lady, L., \& Sucipto, H. (2019). Implementation of a Hydroponic System for Red Chili Seedlings Based on a Green House in Pandeglang Regency. Balireso Journal, 4(2), 22-29. https://doi.org/10.33096/balireso.v4i2.118

Asmal, A. (2018). Analysis of Vitamin C Content in Cayenne Pepper (Capsicum fructuscens L.) Iodimetrically. Journal of Pharmacy Sandi Karsa, IV(7), 99-103.

Assagaf, A. A. R. (2017). Effect of Spacing System and EM-4 Administration on Growth and Production of Cayenne Pepper (Carpsicum frutescent L). Scientific Journal of Agribusiness and Fisheries (Agrikan UMMU-Ternate), 10(2), 65-79. https://doi.org/10.29239/j.agrikan.10.2.65-79

Aswir, M., Ulim, M. A., \& Syamsuddin. (2018). Effect of Varieties and Dosage NPK Mutira of Growth and Crop Production Red Chili (Capsicum annuum L.). Agricultural Student Scientific Journal, 3(4). Retrieved from http://www.jim.unsyiah.ac.id/JFP 
Bete, K., \& Taena, W. (2018). Factors Affecting Production of Red Chili Pepper Farming in Tapenpah Village, Insana District, North Central Timor Regency. Agrimor: Journal of Dryland Agribusiness, 3(1), 7-9. https://doi.org/10.32938/ag.v3i1.240

BPS. (2017). Central Bureau of Statistics. West Nusa Tenggara Province in Number. Retrieved from https://ntb.bps.go.id/publication-2017/08/11/85bf7f9f0d2826ed2a8b2f74/province

BPS. (2019). Cayenne pepper production by province, 2015-2019. Central Bureau of Statistics and Directorate General of Horticulture.

Edi, J., Jannah, N., \& Syahfari, H. (2017). Effect of NPK DGW Compaction Fertilizer and Cow Manure on Growth and Yield of Big Red Chili (Capsicum annuum L.) Arimbi Variety. Jurnal AGROFOR, XVI(1).

Edowai, D. N., Kairupan, S., \& Rawung, H. (2016). Quality of Cayenne Pepper (Capsicum frutescens L.) at Different Maturity Levels and Temperatures during Storage. AGROINTEK, 10(1), 12-20. https://doi.org/ 10.21107/agrointek.v10i1.2021

Effendi, M. A., Asyari, H., \& Gultom, T. (2018). Identification Diversity of Cayenne Pepper (Capsicum frucescent L.) Based on Morphological Characters in Deli Serdang. Proceedings of the National Biology Seminar and Its Learning, Medan State University, Indonesia.

Eliyatiningsih, \& Mayasari, F. (2019). Efficiency of Use of Production Factors in Red Chili Farming in Wuluhan District, Jember Regency. Agrica: Journal of Agribusiness North Sumatra, 12(1). https://doi.org/10.31289/ agrica.v12i1.2192.g1893

Ernita, M., Alhidayati, \& Haryoko, W. (2020). Influence of NPK Fertilizer and Citronella Pesticide Nano on the Growth and Yield Red Chili Plant. Agrotech Journal, 4(2), 1-9. https://doi.org/10.33096/agrotek.v4i2.128

Fitri, Z. E., Nuhanatika, U., \& Madjid, A. (2020). Determination of Maturity Level of Cayenne Pepper (Capsicum frutescens L.) Based on Dray Level Co-Occurrence Matrix. Journal of Applied Information Technology, 7(1), 2580-2291. https://doi.org/10.25047/jtit.v7i1.121

Hayatudin. (2021). The Effect of NPK Fertilizer and Interval of Weeding Time on the Growth and Results of Local Buol Chili (Capsicum frutescens L.). Journal of Agrocomplex Tolis, 1(2), 39-44.

Hutubessy, J. I. B. (2017). The Effect of Phonska NPK Fertilizer on the Growth and Yield of Chili (Capsicum annuum L.) and Red Bottom Intercropping (Allium cepa L.). AGRICA, 10(1), 8-16. https://doi.org/ 10.37478/agr.v10i1.76

Ilyasa, M., Hutapea, S., \& Rahman, A. (2018). Growth Response and Small Chili Plant Production (Capsicum frutescens L.) Against Giving Compost and Biochar from Sugar Cane Waste. Agrotekma: Journal of Agrotechnology and Agricultural Science, 3(1), 81-91. https://doi.org/10.31289/agr.v3i1.1119

Karim, H., Suryani, A. I., Yusuf, Y., \& Fatah, N. A. K. (2019). Growth of Cayenne Pepper (Capsicum frutescens L.) Against Application of Liquid Organic Fertilizer for Banana Kepok Waste. Indonesian Journal of Fundamental Science, 5(2), 91-101. https://doi.org/10.26858/ijfs.v5i2.11110

Kusnadi, J., Andayani, D. W., Subaidah, E., \& Arumingtyas, E. L. (2019). Extraction of Bioactive Compound in Chili Pepper (Capsicum frutescens L.) with Ultrasonic Assisted Extraction Methods. Journal of Agricultural Technology, 20(2), 79-84.

Mahyudi, F. (2015). Sensitivity Analise of Hiyung Chili (Capsicum frutescens L.) Farmer Effort as a Hotest Chili in Indonesia. Media Science, 8(2), 144-149.

Nurjanani. (2016). The Effect of the Use of NPK Fertilizers on the Growth of Chili Plants in the Dry Season. South Sulawesi Agricultural Technology Study Center.

Pasangka, B., \& Irvandi, G. P. (2021). Continuous Development and Cultivation of Soybean as a Result of Multigamma Irradiation through Final Purifying Method. Journal of Research in Science Education, 7(2), 156-166. https://doi.org/10.29303/jppipa.v7i2.611

Pasangka, B., \& Refli. (2016). Development and ultivation of Local Kidney Bean (Phaseolus vulgaris L.) Through Breeding to Use Multigamma Irradiation Technique (Nuclear). American Journal of Agricultural and Biologycal Sciences, 11(3), 117-127. https://doi.org/10.3844/ajabssp.2016.117.127

Prabowo, S. M., Dewi, S. A., \& Susilarto, D. (2018). The Effectiveness of EM4 on Growth Cayenne Pepper (Capsicum frutescens L.). AGRIC: Journal of Agricultural Science, 30(1), 15-24. https://doi.org/10.24246/ agric.2018.v30.i1.p15-24 
Putri, Y. R., Khuriyati, N., \& Sukartiko, A. C. (2020). Effect of Temperature and Packaging on Physical Quality of Curly Red Chili (Capsicum annuum L.) During Storage. Journal of Agricultural Technology, 21(2), 89-93.

Salampessy, Y. E., Timisela, N. R., \& Apituley, Y. M. T. N. (2019). Marketing Channels of Cayenne Peppers and Anions in Ambon City. AGRILAN: Archipelago Agribusiness Journal, 7(3), 255-264. https://doi.org/ 10.30598/agrilan.v7i3.941

Septiadi, D., Sari, N. M. W., \& Zainuddin, A. (2020). Analysis of Cayenne Pepper Consumption Demand in Households in Mataram City. Agrimor: Dryland Agribusiness Journal, 5(2), 36-39. https://doi.org/ 10.32938/ag.v5i2.1013

Silvia, M., Susanti, H., Samharinto, \& Noor, G. M. S. (2016). Production of Chili (Capsicum frutescens L.) in Ultisol Soil Using Organic Household Waste Bokashi and NPK. Enviro Scienteae, 12(1), 22-27. https://doi.org/10.20527/es.v12i1.1096

Sofa, M. F., Saparto, \& Wiharso. (2019). The Effect of Cost of Production Facilities and Labor on the Income of Cayenne in Kesambi Village Mojobo District Kudus Regency. AGROMEDIA, 37(1), 93-101. https://doi.org/ 10.47728/ag.v37i1.249

Sutomo, Rahmawati, A., \& Rizki, M. I. (2017). Standardization of Rawit Hiyung Chili (Capsicum frutescens L.) from South Kalimantan Tapin. Scientific Journal of Ibnu Sina, 2(2), 245-253.

Undang, Syukur, M., \& Sobir. (2015). Identification of Capcicum Species Based on Competitiveness and Morphological Characters. J. Agron. Indonesia, 43(2), 118-125. https://doi.org/10.24831/jai.v43i2.10413

Wachdijono. (2020). The nature of the elasticity of demand for cayenne pepper in two conditions of price changes in the city of Cirebon. COMPOSITE: Journal of Agricultural Sciences, 02(1), 1-10. https://doi.org/10.37577/composite.v2i1.156

Wulandari, A., Hendarto, K., Andalasari, T. D., \& Widagdo, S. (2018). Effect of NPK Fertilizer Dosage and Application of Leaf Fertilizer on the Growth of Curly Chili (Capsicum annuum L.) seedlings. J. Agrotek. Tropica, 6(1), 8-14. https://doi.org/10.23960/jat.v6i1.2526

\section{Copyrights}

Copyright for this article is retained by the author(s), with first publication rights granted to the journal.

This is an open-access article distributed under the terms and conditions of the Creative Commons Attribution license (http://creativecommons.org/licenses/by/4.0/). 